\section{Undergraduate medical education and the future of surgery}

Advances in fields such as genomics, artificial intelligence (AI) and robotics are increasingly shaping a transformational future for the practice of surgery. ${ }^{1}$ It provides current medical students with an interest in surgery the potential to be a part of an exciting change in surgical practice. However, in comparison to the widely cited opportunities for surgical transformation in coming times, there are relatively few articles discussing the ways in which medical education will keep pace with these changes. The Royal College of Surgeons recently published a guide concerning the future of surgery ${ }^{2}$ within which it discusses the growing need for the future surgical workforce to be composed of multifaceted individuals with an understanding of disciplines such as bioengineering, genetics, entrepreneurship and management. The report emphasises the importance of adapting surgical training to these advances in science and technology.

However, it is also important to consider the role of undergraduate medical education in the future of surgery. If training programmes are to attract those multifaceted individuals that the future surgical workforce needs, then medical schools must expose students to the aforementioned subjects and nurture their interests in an environment that reflects the innovations transforming healthcare. This can be done by integrating and adapting current technology such as AI and robotics into medical education, similar to that of virtual reality platforms increasingly being used in anatomy demonstration. ${ }^{3}$ A greater focus can also be placed on intercalated degrees in subjects such as data science, bioengineering and healthcare management, currently available at only a handful of UK institutions.

In summary, when considering the evolution of the surgical workforce in preparation for advances in healthcare we must also consider undergraduate medical education. This essential if growing demands in surgery are to be met with an equipped and forward-thinking workforce, ready to take on the challenges and opportunities of modern-day surgical practice.

\section{Hanad Ahmed $\odot,{ }^{1}$ Laurence Devoto ${ }^{2}$}

${ }^{1}$ Faculty of Medicine, University of Southampton, Southampton, UK

${ }^{2}$ Department of Surgery and Interventional Science, University College London Hospitals NHS Foundation Trust, London, UK

Correspondence to Hanad Ahmed, University of Southampton Faculty of Medicine, Southampton S017 1BJ, UK; Ha1g14@soton.ac.uk

Contributors Written by HA with supervision and input from LD.

Funding The authors have not declared a specific grant for this research from any funding agency in the public, commercial or not-for-profit sectors.

Competing interests None declared.

Patient consent for publication Not required.
Provenance and peer review Not commissioned; internally peer reviewed.

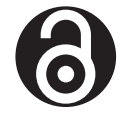

\section{OPEN ACCESS}

Open access This is an open access article distributed in accordance with the Creative Commons Attribution Non Commercial (CC BY-NC 4.0) license, which permits others to distribute, remix, adapt, build upon this work non-commercially, and license their derivative works on different terms, provided the original work is properly cited, appropriate credit is given, any changes made indicated, and the use is non-commercial. See: http://creativecommons.org/ licenses/by-nc/4.0/.

(C) Author(s) (or their employer(s)) 2021. Re-use permitted under CC BY-NC. No commercial re-use. See rights and permissions. Published by BMJ.

Check for updates

To cite Ahmed H, Devoto L. Postgrad Med J Epub ahead of print: [please include Day Month Year]. doi:10.1136/postgradmedj-2020-139125

Accepted 11 October 2020

Postgrad Med J 2021;0:1.

doi:10.1136/postgradmedj-2020-139125

ORCID iD

Hanad Ahmed http://orcid.org/0000-0002-4077-4161

\section{REFERENCES}

1 Alderson D. The future of surgery. Br J Surg 2018;106:9-10.

2 RCS. Welcome to the future of surgery. future of surgery, 2020. Available: https://futureofsurgery.rcseng. ac.uk/?_ga=2.61413036.1293217085.1595699109653186564.1595699109 [Accessed 2 Aug 2020].

3 Guze PA. Using technology to meet the challenges of medical education. Trans Am Clin Climatol Assoc 2015;126:260-70. 